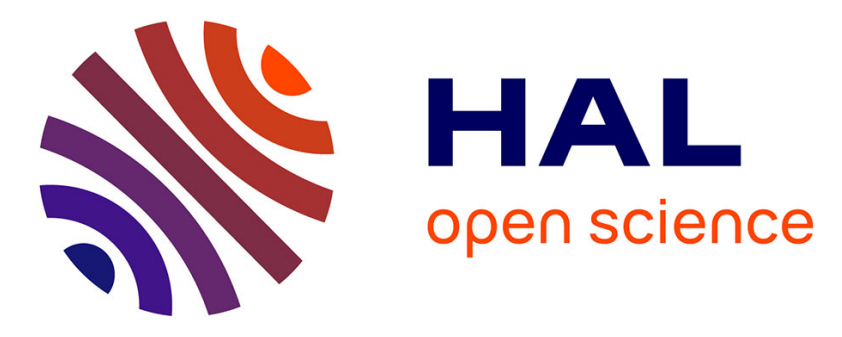

\title{
Cardiac arrest in the workplace and its outcome: a systematic review and meta-analysis.
}

Alexis Descatha, Céline Dagrenat, Pascal Cassan, Daniel Jost, Thomas Loeb, Michel Baer

\section{- To cite this version:}

Alexis Descatha, Céline Dagrenat, Pascal Cassan, Daniel Jost, Thomas Loeb, et al.. Cardiac arrest in the workplace and its outcome: a systematic review and meta-analysis.: Meta-analysis Cardiac arrest in the workplace . Resuscitation, 2015, 96, pp.30-6. 10.1016/j.resuscitation.2015.07.004 . inserm01311836

\section{HAL Id: inserm-01311836 https://www.hal.inserm.fr/inserm-01311836}

Submitted on 4 May 2016

HAL is a multi-disciplinary open access archive for the deposit and dissemination of scientific research documents, whether they are published or not. The documents may come from teaching and research institutions in France or abroad, or from public or private research centers.
L'archive ouverte pluridisciplinaire HAL, est destinée au dépôt et à la diffusion de documents scientifiques de niveau recherche, publiés ou non, émanant des établissements d'enseignement et de recherche français ou étrangers, des laboratoires publics ou privés. 
Cardiac arrest in the workplace and its outcome: a systematic review and meta-analysis

\author{
Alexis Descatha ${ }^{1,2,3,4}$, Céline Dagrenat ${ }^{1}$, Pascal Cassan ${ }^{5}$, Daniel Jost ${ }^{6,7}$, Thomas Loeb ${ }^{1}$, \\ Michel Baer'. \\ 1. AP-HP, EMS (Samu92) Occupational Health Unit, University hospital of West suburb \\ of Paris, Poincaré site, F92380 Garches, France \\ 2. Versailles St-Quentin University UVSQ, UMS 011, UMR-S 1168, France \\ 3. Inserm, Population-based Epidemiologic Cohorts Unit, UMS 011, Villejuif, France \\ 4. Inserm, VIMA : Aging and chronic diseases. Epidemiological and public health \\ approaches, U1168, F-94807, Villejuif, France \\ 5. International Federation of Red Cross and Red Crescent Societies, Global First Aid \\ Reference Centre, Paris, France \\ 6. Emergency Medical Unit, Paris Fire Brigade, Paris, France \\ 7. Sudden Death Expertise Center (SDEC) INSERM U 970 - Paris- France
}

Address for reprints: Prof. Alexis Descatha, Unité de pathologie professionnelle SAMU92, CHU Poincaré, 104 bd Poincaré, 92380 Garches, France

Tel: +33 (1) 471077 64; Fax: +33 (1) 471077 68; email: alexis.descatha@inserm.fr

Running title. Meta-analysis Cardiac arrest in the workplace

Key words: cardiac arrest; location; public; work; occupational; review; meta-analysis; prevention.

All authors have participated in the conception and design of the study, or the acquisition of data, or the analysis and interpretation of the data, drafting the article, or revising it critically for important intellectual content, and final approval of the version submitted. 
Introduction.Out-of-hospital cardiac arrest (OHCA) in the workplace appears to be managed more effectively than OHCA occurring in other places. A systematic review and metaanalysis of the available epidemiological data was performed, comparing the rate of survival for OHCA in the workplace, versus survival in other locations.

Methods.Four databases (Pub-Med, Scopus, Web of science, "Base de Données de Santé Publique”, BDSP, i.e. the French Public Health Database) were searched since 2000, using the key words: ("Cardiac arrest") and ("occupational" OR "workplace" OR "public location"). A two stage process with two independent readers was used to select relevant papers. Numbers of subjects who suffered fromOHCA in the workplace versus other locations were extracted when possible, as well as their respective outcomes (admitted alive to the hospital, discharged alive, good neurological outcome). Metarisks were calculated using the generic variance approach (meta-odds ratiosmetaOR).

Results After full-text reading, 17papers were included, from 9 countries, mostly published after 2005, and coming mostly from prospective registers. "Workplace" was defined differently in different studies, mostly in terms of industrial sites and offices. The workplace was an exceptional location for occurrences of OHCA (from $0.3 \%$ to $4.7 \%$ of all OHCA, from 1.3 to 23.8 events per million peoplePeryear), based on 2077 OHCA.In thequantitative analyses (survival available, 10 studies), MetaOR were found to be relatively consistent and high (form $1.9(1.5-2.3)$ to $5.9(2.7-13.0)$ ). When OHCA occurring at workplaces were compared to other public sites, no significant differences were found.

Conclusion.There is sufficient evidence to support the view that there will be better outcomes for OHCA cases that occur in the workplace than for those occurring elsewhere. Requirements for occupational health and safety should include prevention of such major (albeit rare) events. 
IntroductionSince the survival rate decreases exponentially with increases in the interval between out-of-hospital cardiac arrest (OHCA) and the chain of survival, the locations of first responders, their training level, and the location of automated external defibrillators (AED) are particularly important. ${ }^{[1]}$

Despite its relatively low incidence, it has been suggested that OHCA in the workplace appears to be managed more effectively than OHCA occurring in other places, which encourages the setting up of first-aid programs in certain companies. ${ }^{[2]}$.Some studiesthat compare OHCA managed in the workplace versus OHCAmanaged atother locationshave recently been published ${ }^{[3-5]}$.

The goal of this study was to undertake a systematic review and meta-analysis of the available epidemiological data, comparing the rate of survivalfor OHCA in the workplace, versus survival atother locations. The proportion of workplace OHCA in relation toother locations and its frequencyare also described, if available.

\section{Methods}

\section{Literature research}

Four databases (Pub-Med, Scopus, Web of science, "Base de Données de Santé Publique", BDSP, i.e. the French Public Health Database) were searched, using the key words: ("Cardiac arrest") and (“occupational” OR "workplace” OR "public location”). No language limitation was added. Papers published before the recommendations ofthe International Liaison Committee on Resuscitation (ILCOR) of 2000 were considered too old ${ }^{[6]}$. The first selection of articles was performed by two independent readers (A.D. and C.D.). The aim, based on the title and abstract, was to include only papers with (i) original studies dealing with cardiac 
arrest, (ii) sufficient details to distinguish workplace locationsfrom otherlocations (public or private),(iii) outcomes respecting the Utstein recommendations ${ }^{[7,8]}$. The second stage included examination of full-text papers based on the same criteria. Studies meeting these criteria were included in the meta-analysis after a review by the independent readers (A.D. and C.D.).

\section{Assessment of methodological quality}

Alist evaluating methodological quality in terms of four categories was created, adapted from Utstein style and Prisma recommendations ${ }^{[7-9]}$. The five relevant questionswere:(i) was the study design exhaustive? (i.e. with data from a register), (ii) was the workplace location defined precisely?(iii) didthe outcome of OHCA patients include survival at 6months with neurological evaluation? (iv) wasthe proportion of treatable OHCA available ? (i.e. not traumatic, shockable, rhythm, withwitnesses) (v) How recent were the studies? (performed in the last 10 years). Two reviewers (A.D. and C.D.) independently assessed the quality of each study by scoring each criterion as positive or negative. Disagreement was resolved by consensus. The fair quality score was based on a total score of 3 or higher.

\section{Data extraction and analysis}

Relevant data were extracted from the articles: the number of workplace OHCA, their frequency,and their survival were extracted, as well as the number of thoserelated to other locations. Frequency of OHCA wasalso extracted, if available. The core findings in each article were expressed using measures of association (odds ratio or OR) with a corresponding 95\% confidence interval (CI).Three outcomes were considered: (i) admitted alive to hospital, (ii) discharged alive from hospital or still alive 30 days after the OHCA, (iii) favorable neurological outcome (i.e. Cerebral Performance Category (CPC) 1: return to normal cerebral function and normal living, or CPC 2: cerebral disability, but sufficient function for 
independent activities of daily living). Whenever possible, these associations were directly extracted from the original article. In articles where this information was not available, associations were calculated when sufficient raw data was provided. Raw data were requested from all authors if needed. Some were unable to give us authorization for access to the raw data. Nevertheless, metarisks(meta-OR) were calculated using the generic variance approach. The weight given to each studywas the inverse of the variance of the estimated effect. Heterogeneity was tested with the Q statistic. From the Q statistic, we calculated a summary OR and 95\% CI with the random effect method. This approach provides more conservative estimates (broader CI) than a fixed effect model, assuming that the differences between results are solely due to chance. For each outcome, all OHCA were included and only those considered as treatable (excluding OHCA without any witness, with traumatic cause,with non-shockable rhythm, depending on available data). To compare workplaces with other public sites, we also recalculated meta-OR for such treatable OHCA.

We tested the publication bias due to study size using Egger's regression approach. Meta-ORs were run on all studies, and on fair quality methodological studies only.

The meta-analysis was performed using STATA (Version 11.2; Stata Corp., College Station, TX, USA). The PRISMA checklist wasused. ${ }^{[9]}$

\section{Results}

In the four selected data bases, we found 30 papers corresponding to our first stage (Figure 1). Only two papers were included due to cross-references (in the reference list and not in the databases), and neither of these? was selected after full-reading. After full-text reading, 17 papers were included ${ }^{[10-12,3,13,14,4,15,5,16-23]}$. Agreement between the two reviewers was good (kappa 0.90). Selected studies came from nine countries (mostly from the United States, Japan, and France), and were mostly published after 2005 (Table 1).Data were obtained 
mostly from prospective registers.No discrepancy between the readers was found (considering the simple but robust criteria). "Workplace" was defineddifferently in different studies, mostly in terms of industrial sites and offices. The workplace was an exceptional location for occurrences of $\mathrm{OHCA}$ (from $0.3 \%$ to $4.7 \%$ of all $\mathrm{OHCA}$, from 1.3 to 23.8 events per million people per year), based on 2077 OHCA.

Of the remaining 17 papers, 10for which survival data were available andwere selected in the quantitative analysis review: ${ }^{[10-12,3,13,14,4,15,5,16]}$ Except for one of them, these studies found a better outcomefor OHCA occurring in workplaces than OHCA occurring elsewhere ( $n=1383$ ), and metaORswere found to be relatively consistent and high(Table 2), taking into account all outcomes. Sensitivity analyses based on recent and fair quality methodological studies found similar results. There was no significant publication bias (Egger's test, $\mathrm{P}>0.05$ ). When OHCA occurring at workplaces were compared to those at other public sites, no significant differences were found.

\section{Discussion}

Results reported in the literature from the last fifteen years are consistent, and confirm that the workplace locationseems to bea safer place than any other, with a better rate of survival observed in such locations, althoughsuch OHCA remain an exceptional event. However, improvement of OHCA handling in workplaces seems necessary when compared to outcomes involvingother public places only.

Most of the difficulties with the studies about the management of OHCA in the workplacecome from the heterogeneous definition of "workplace", which ranges from small 
shops to large factories, construction sites to small businesses etc. Thus, comparing outcomes involving different definitions of the workplace is debatable, given that the term "location elsewhere" is also very vague. Although most of the workplaces described were classified as "industry and business", the definition of such locations remains quite broad. However, all workplaces share similar characteristics, such as relatively young age of the patient and the presence of witnesses, and similar interpretations for what counts as a workplace. Although studies are needed to analyze, in greater detail, differences in thesurvival chain for the differentkinds of workplaces, the homogeneity of our results allows general recommendations to be proposed concerning the prevention and management of cardiac arrest cases in workplaces.

The similarity in results observed for workplaces raises the question of why outcomes are better there than elsewhere. Three explanations are plausible: first, people are usually healthier at work than elsewhere: the "healthy worker effect". This major difference between workplaces and private and/or other public sites, is visible in the younger ages of patients, and the rarity of this type of event, even though the medical condition, usually better, is not reported in these studies. Some studies have tried to minimize the impact of such effects. Two authors used matched controls on age to have similar patternsfor subjects, and were considered in the meta-analysis. However, chronic illnesses were not considered, and the better survival observed is partly explained by the fact that people in workplaces generally are healthier than those in other locations, which would explain the low incidence. Nevertheless, it also is quite plausiblethat improved management of OHCA at workplace locations might be very efficient, taking into accountthe high number of years of life saved in good conditions. Second, for business and industry, in general, the workplace is also characterized by a higher density of people working together, as with other public locations. However, specific 
guidelines for workplaces also result in better management of events, with first-aid, and automated external defibrillator implementation, recommended. ${ }^{[2,24]}$ Third, specific efforts have been made by many employers and occupational health practitioners to improve working conditions and prevent, as much as possible, the occurrence of cardiac arrest (prevention of major injuries, suicide attempts related to occupational psychosocial factors, etc...). Since we were notable to find better outcomesfor workplacesthan for other public sites, improvement in prevention and OHCA management guidelines should be a priority all over the world, again considering the gainin number of years of life under good conditions ${ }^{[25]}$.

Some limitations should be considered concerning the methodology used. First, publication bias should be discussed. Even though the meta-analysis is based on a small number of studies retained, the results of the papers included seem to be coherent and quite homogeneous, and Egger's test do not reveal a major publication bias, such as Funnel plot (results not shown). The choice of the outcomes used to express the results of the metaanalysis may also raise questions. We decided not to include returns to spontaneous circulation as an outcome, and to adopt a broad definition of treatable OHCA. However, these simplifications did allow us to group the data using broad definitions based on different criteria. Furthermore, if raw data had been accessible, better definitions of treatable OHCA would have been available, but would probably have led to higher odds ratios. Pooled metaAnalysis was not possible because some data were not accessible, even though some authors did send us raw data.

In conclusion, there issufficient evidence to support the view that there are better outcomes for OHCA cases that occur in the workplace than for those occurring elsewhere. 
Requirements for occupational health and safety should include prevention of such major (albeit rare) events, by requiring first-aid and automated external defibrillators, as some countries already do ${ }^{[26,27,24]}$. Research papers should also distinguish the workplace from other public sites, with a special focus on the details of the workplace environment. 


\section{Acknowledgments}

The authors would like to thank DrFritz Sterz and DrPhilip Eisenburger, and the RéAC study group. We also thank Richard Carter for helpingus to improve the language of this work.

\section{Conflict of interest statement}

No relevant conflicts of interest. The authors are paid for their respective affiliations. In addition, Alexis Descathahas received money for his editing work (He is Editor in chief of Archives des maladies professionnelles) from Elsevier Masson.

\section{References}

1. Nolan JP, Soar J, Perkins GD. Cardiopulmonary resuscitation. BMJ 2012;345:e6122.

2. Descatha A, Baer M. Automated external defibrillators in the workplace. BMJ 2008;337(oct08_1):a1816.

3. Muraoka H, Ohishi Y, Hazui H, Negoro N, Murai M, Kawakami M, et al. Location of out-of-hospital cardiac arrests in Takatsuki City: where should automated external defibrillator be placed. Circ.J. 2006;70(7):827-31.

4. Descatha A, Jost D, Carpentier JP. Is the workplace a site of cardiac arrest like any other? Resuscitation 2009;80(5):602-3.

5. Murakami Y, Iwami T, Kitamura T, Nishiyama C, Nishiuchi T, Hayashi Y, et al. Outcomes of out-of-hospital cardiac arrest by public location in the public-access defibrillation era. J. Am. Heart Assoc. 2014;3(2):e000533.

6. Monsieurs KG, Handley AJ, Bossaert LL, European Resuscitation Council. European Resuscitation Council Guidelines 2000 for Automated External Defibrillation. A statement from the Basic Life Support and Automated External Defibrillation Working Group(1) and approved by the Executive Committee of the European Resuscitation Council. Resuscitation 2001;48(3):207-9.

7. Cummins RO, Chamberlain DA, Abramson NS, Allen M, Baskett PJ, Becker L, et al. Recommended guidelines for uniform reporting of data from out-of-hospital cardiac arrest: the Utstein Style. A statement for health professionals from a task force of the American Heart Association, the European Resuscitation Council, the Heart and Stroke Foundation of Canada, and the Australian Resuscitation Council. Circulation 1991;84(2):960-75. 
8. Peberdy MA, Cretikos M, Abella BS, DeVita M, Goldhill D, Kloeck W, et al. Recommended guidelines for monitoring, reporting, and conducting research on medical emergency team, outreach, and rapid response systems: an Utstein-style scientific statement: a scientific statement from the International Liaison Committee on Resuscitation (American Heart Association, Australian Resuscitation Council, European Resuscitation Council, Heart and Stroke Foundation of Canada, InterAmerican Heart Foundation, Resuscitation Council of Southern Africa, and the New Zealand Resuscitation Council); the American Heart Association Emergency Cardiovascular Care Committee; the Council on Cardiopulmonary, Perioperative, and Critical Care; and the Interdisciplinary Working Group on Quality of Care and Outcomes Research. Circulation 2007;116(21):2481-500.

9. Liberati A, Altman DG, Tetzlaff J, Mulrow C, Gotzsche PC, Ioannidis JP, et al. The PRISMA statement for reporting systematic reviews and meta-analyses of studies that evaluate health care interventions: explanation and elaboration. PLoS.Med. 2009;6(7):e1000100.

10. Pell JP, Sirel JM, Marsden AK, Ford I, Walker NL, Cobbe SM. Potential impact of public access defibrillators on survival after out of hospital cardiopulmonary arrest: retrospective cohort study. BMJ 2002;325(7363):515-9.

11. Descatha A, Frederic M, Devere C, Dolveck F, Goddet S, Baer M, et al. Details of the initial management of cardiac arrest occurring in the workplace in a French urban area. Resuscitation 2005;65(3):301-7.

12. Eisenburger P, Sterz F, Haugk M, Scheinecker W, Holzer M, Koreny M, et al. Cardiac arrest in public locations--an independent predictor for better outcome? Resuscitation 2006;70(3):395-403.

13. Reed DB, Birnbaum A, Brown LH, O’Connor RE, Fleg JL, Peberdy MA, et al. Location of cardiac arrests in the public access defibrillation trial. Prehosp.Emerg.Care 2006;10(1):61-76.

14. Iwami T, Hiraide A, Nakanishi N, Hayashi Y, Nishiuchi T, Uejima T, et al. Outcome and characteristics of out-of-hospital cardiac arrest according to location of arrest: A report from a large-scale, population-based study in Osaka, Japan. Resuscitation 2006;69(2):221-8.

15. Descatha A, Rigot H, Ursat C, Baer M, Loeb T, GR-RéAC, RéAC Collaborative Group. Cardiac arrest in the workplace: pilot study on the RéAC register. Resuscitation 2013;84(6):e65-6.

16. Weisfeldt ML, Sitlani CM, Ornato JP, Rea T, Aufderheide TP, Davis D, et al. Survival after application of automatic external defibrillators before arrival of the emergency medical system: evaluation in the resuscitation outcomes consortium population of 21 million. J. Am. Coll. Cardiol. 2010;55(16):1713-20.

17. Zakaria ND, Ong MEH, Gan HN, Foo D, Doctor N, Leong BS-H, et al. Implications for public access defibrillation placement by non-traumatic out-of-hospital cardiac arrest occurrence in Singapore. Emerg. Med. Australas. EMA 2014;26(3):229-36. 
18. Malcom GE, Thompson TM, Coule PL. The location and incidence of out-of-hospital cardiac arrest in Georgia: implications for placement of automated external defibrillators. Prehospital Emerg. Care Off. J. Natl. Assoc. EMS Physicians Natl. Assoc. State EMS Dir. 2004;8(1):10-4.

19. Folke F, Lippert FK, Nielsen SL, Gislason GH, Hansen ML, Schramm TK, et al. Location of cardiac arrest in a city center: strategic placement of automated external defibrillators in public locations. Circulation 2009;120(6):510-7.

20. Engdahl J, Herlitz J. Localization of out-of-hospital cardiac arrest in Goteborg 19942002 and implications for public access defibrillation. Resuscitation 2005;64(2):171-5.

21. Moon S, Vadeboncoeur TF, Kortuem W, Kisakye M, Karamooz M, White B, et al. Analysis of out-of-hospital cardiac arrest location and public access defibrillator placement in Metropolitan Phoenix, Arizona. Resuscitation 2015;

22. Brooks SC, Hsu JH, Tang SK, Jeyakumar R, Chan TCY. Determining risk for out-ofhospital cardiac arrest by location type in a Canadian urban setting to guide future public access defibrillator placement. Ann. Emerg. Med. 2013;61(5):530-8.e2.

23. Hansen CM, Wissenberg M, Weeke P, Ruwald MH, Lamberts M, Lippert FK, et al. Automated external defibrillators inaccessible to more than half of nearby cardiac arrests in public locations during evening, nighttime, and weekends. Circulation 2013;128(20):2224-31.

24. Rudner R, Jałowiecki P, Wartak M, Marciniak R, Byrczek T. The effects of selected factors on survival of out-of-hospital cardiac arrest victims. Anestezjol. Intensywna Ter. 2005;37(3):174-80.

25. Chamoux A, Dang C, Soula MC, Dolveck F, Havette P, Coudurier F, et al. Place du médecin du travail dans l'organisation des urgences en milieu de travail. Arch. Mal. Prof. Environ. 2009;70(2):174-81.

26. Papaleo B, Cangiano G, Calicchia S, Marcellini L, Colagiacomo C, Pera A. Organization and management of first aid in workplaces: Critical aspects and innovations to be introduced. G. Ital. Med. Lav. Ergon. 2012;34(1):71-5.

27. Starr LM. Automated external defibrillation in the occupational setting. J. Occup. Environ. Med. 2012;54(9):1170-6. 
Table 1. Studies included.

\begin{tabular}{|c|c|c|c|c|c|c|c|c|c|}
\hline $\begin{array}{c}\text { First } \\
\text { author }\end{array}$ & Country & Where/When? & Type of study & $\begin{array}{c}\text { Type of } \\
\text { Workplace }\end{array}$ & $\begin{array}{c}\text { Numb } \\
\text { er of } \\
\text { OHCA } \\
\text { at } \\
\text { workpl } \\
\text { ace }\end{array}$ & $\begin{array}{c}\text { Proporti } \\
\text { on of } \\
\text { OHCA } \\
\text { at } \\
\text { workpla } \\
\text { ce/ } \\
\text { elswhere }\end{array}$ & $\begin{array}{c}\text { Number of } \\
\text { OHCA at } \\
\text { workplace/ } \\
\text { Inhabitants (in } \\
\text { number by } \\
\text { years/millions } \\
\text { of inhabitants) }\end{array}$ & $\begin{array}{c}\text { Survival on workplace } \\
\text { versus elsewhere } \\
\text { (respectively) }\end{array}$ & $\begin{array}{l}\text { Fairqual } \\
\text { ity?(Scor } \\
\text { e) }\end{array}$ \\
\hline $\begin{array}{l}\text { Descatha } \\
2005(11)\end{array}$ & France & $\begin{array}{c}\text { Paris West } \\
\text { Suburb 1993- } \\
2002\end{array}$ & $\begin{array}{c}\text { Retrospective } \\
\text { Case-Control } \\
\text { studyfrom a } \\
\text { prospective } \\
\text { database }\end{array}$ & $\begin{array}{l}\text { All workplace } \\
\text { type (detailed } \\
\text { and checked); }\end{array}$ & 72 & $2.00 \%$ & 14.9 & $\begin{array}{c}\operatorname{Adm}_{\text {all }} 22.2 \% \text { vs } 17.7 \% \\
\text { Adm.Treatable } 25.5 \% \text { vs } 18.0 \% \\
\text { Disch.All } 8.3 \% \text { vs } 4.2 \% \\
\text { Disch.Treatable } 9.1 \% \text { vs } 6.0 \%\end{array}$ & No (1) \\
\hline $\begin{array}{l}\text { Descatha } \\
2009 \text { (4) }\end{array}$ & France & $\begin{array}{c}\text { Paris Suburb } \\
2004\end{array}$ & $\begin{array}{l}\text { Retrospective } \\
\text { analysis of a } \\
\text { prospective } \\
\text { register }\end{array}$ & $\begin{array}{l}\text { Workplace (not } \\
\text { specified) }\end{array}$ & 61 & $2.65 \%$ & 7.4 & $\begin{array}{c}\text { Adm.all } 31.1 \% \text { vs } 19.6 \% \\
\text { Adm.Treatable } 45.5 \% \text { vs } 26.3 \%\end{array}$ & No (2) \\
\hline $\begin{array}{l}\text { Descatha } \\
2013(15)\end{array}$ & France & $\begin{array}{c}\text { France 2011- } \\
2012\end{array}$ & $\begin{array}{l}\text { Case -control } \\
\text { study in a } \\
\text { prospective } \\
\text { nationwide } \\
\text { register }\end{array}$ & $\begin{array}{l}\text { Workplace (not } \\
\text { specified) }\end{array}$ & 113 & $4.70 \%$ & 1.6 & $\begin{array}{c}\text { Adm.all } 36.3 \% \text { vs } 15.6 \% \\
\text { Adm.Treatable } 25.5 \% \text { vs } 18.0 \% \\
\text { CPC } 1 / 2_{\text {All }} 9.7 \% \text { vs } 2.9 \% \\
\text { CPC } 1 / 2_{\text {treatable }} 15.7 \% \text { vs } 3.3 \%\end{array}$ & Yes (3) \\
\hline $\begin{array}{l}\text { Eisenberg } \\
2006(12)\end{array}$ & Austria & $\begin{array}{l}\text { Vienna 1993- } \\
2002\end{array}$ & $\begin{array}{l}\text { Retrospective } \\
\text { study from } \\
\text { prospective } \\
\text { register }\end{array}$ & $\begin{array}{c}\text { Office and } \\
\text { construction site }\end{array}$ & 16 & $0.99 \%$ & $\mathbf{1 . 0}$ & Adm. Treatable $25.0 \%$ vs $29.5 \%$ & No (2) \\
\hline $\begin{array}{c}\text { Iwami } 2006 \\
\text { (14) }\end{array}$ & Japan & $\begin{array}{l}\text { Osaka 1998- } \\
2000\end{array}$ & $\begin{array}{l}\text { Retrospective } \\
\text { study from } \\
\text { prospective } \\
\text { register }\end{array}$ & $\begin{array}{l}\text { Workplace (not } \\
\text { specified) }\end{array}$ & 241 & $1.77 \%$ & 9.1 & $\begin{array}{c}\text { Disch. }_{\text {All }} 5.8 \% \text { vs } 1.4 \% \\
\text { Disch.Treatable } 10.3 \% \text { vs } 2.6 \%\end{array}$ & Yes (3) \\
\hline $\begin{array}{c}\text { Murakimi } \\
2014(5)\end{array}$ & Japan & $\begin{array}{l}\text { Osaka 2005- } \\
2011\end{array}$ & $\begin{array}{l}\text { Prospective } \\
\text { population- } \\
\text { based study }\end{array}$ & $\begin{array}{l}\text { Workplace (not } \\
\text { specified) }\end{array}$ & 306 & $0.68 \%$ & 5.0 & $\begin{array}{l}\text { Adm. Treatable } 51.6 \% \text { vs } 39.5 \% \\
\text { Disch.Treatable } 32.0 \% \text { vs } 12.7 \% \\
\text { CPC } 1 / 2_{\text {treatable }} 22.2 \% \text { vs } 7.3 \%\end{array}$ & Yes (4) \\
\hline $\begin{array}{l}\text { Muraoka } \\
2006(3)\end{array}$ & Japan & $\begin{array}{c}\text { Takatsuki city } \\
1999-2004\end{array}$ & $\begin{array}{l}\text { Retrospective } \\
\text { study from } \\
\text { prospective } \\
\text { register }\end{array}$ & $\begin{array}{l}\text { Factory/office } \\
\text { and Storehouse }\end{array}$ & 17 & $1.54 \%$ & 7.9 & $\begin{array}{l}\text { Disch.Treatable } 23.5 \% \text { vs } 4.7 \% \\
\text { CPC } 1 / 2_{\text {treatable }} 17.6 \% \text { vs } 1.0 \%\end{array}$ & Yes (3) \\
\hline $\begin{array}{l}\text { Pell } 2002 \\
\quad(10)\end{array}$ & $\begin{array}{c}\text { United } \\
\text { Kingdom }\end{array}$ & $\begin{array}{l}\text { Scotland 1991- } \\
1998\end{array}$ & $\begin{array}{l}\text { Retrospective } \\
\text { cohort study } \\
\text { from } \\
\text { prospective } \\
\text { register }\end{array}$ & $\begin{array}{l}\text { Other place of } \\
\text { work }\end{array}$ & 466 & $3.12 \%$ & 12.8 & Disch.Treatable $11.9 \%$ vs $7.8 \%$ & No (2) \\
\hline $\begin{array}{c}\text { Reed } 2006 \\
\text { (13) }\end{array}$ & $\begin{array}{c}\text { United } \\
\text { States and } \\
\text { Canada }\end{array}$ & $\begin{array}{c}\text { PAD data }-3 \\
2000-2003\end{array}$ & $\begin{array}{l}\text { Post-hoc } \\
\text { analysis of a } \\
\text { randomized- } \\
\text { control trial }\end{array}$ & $\begin{array}{c}\text { Offices } \\
\text { andindustrialco } \\
\text { mplex }\end{array}$ & 19 & $3.04 \%$ & 8.0 & Disch. $_{\text {Treatable }} 6.3 \%$ vs $18.2 \%$ & Yes (3) \\
\hline $\begin{array}{l}\text { Weisfeldt } \\
2010(16)\end{array}$ & $\begin{array}{c}\text { United } \\
\text { States and } \\
\text { Canada }\end{array}$ & $\begin{array}{c}\text { US and Canada } \\
2005-2007\end{array}$ & $\begin{array}{c}\text { Prospective } \\
\text { cohort study for } \\
\text { a from } \\
\text { prospective } \\
\text { register }\end{array}$ & Industrial site & 72 & $0.52 \%$ & 2.4 & Disch.Treatable $_{16.7 \%}$ vs $9.6 \%$ & Yes (4) \\
\hline $\begin{array}{c}\text { Brooks } \\
2013(22)\end{array}$ & Canada & $\begin{array}{l}\text { Toronto 2006- } \\
2010\end{array}$ & $\begin{array}{l}\text { Retrospective } \\
\text { study from } \\
\text { prospective } \\
\text { register }\end{array}$ & Industrial & 39 & $0.27 \%$ & 1.3 & $\mathrm{NI}^{*}$ & $\mathrm{NI}^{*}$ \\
\hline $\begin{array}{c}\text { Engdahl } \\
2005(20)\end{array}$ & Sweden & $\begin{array}{c}\text { Göteborg 1994- } \\
2002\end{array}$ & $\begin{array}{l}\text { Retrospective } \\
\text { study from } \\
\text { prospective } \\
\text { register }\end{array}$ & $\begin{array}{l}\text { Worksites not } \\
\text { accessible to the } \\
\text { public such as } \\
\text { industrial sites } \\
\text { and warehouses }\end{array}$ & 22 & $1.00 \%$ & 5.4 & $\mathrm{NI}^{*}$ & $\mathrm{NI}^{*}$ \\
\hline $\begin{array}{c}\text { Folke } 2009 \\
\text { (19) }\end{array}$ & Danemark & $\begin{array}{c}\text { Copenhagen } \\
1994-2005\end{array}$ & $\begin{array}{l}\text { Retrospective } \\
\text { study from } \\
\text { prospective } \\
\text { register } \\
\end{array}$ & $\begin{array}{l}\text { Large industrial } \\
\text { business }\end{array}$ & 164 & $1.29 \%$ & 22.8 & $\mathrm{NI}^{*}$ & $\mathrm{NI}^{*}$ \\
\hline $\begin{array}{c}\text { Hansen } \\
2013(23)\end{array}$ & Danemark & $\begin{array}{c}\text { Copenhagen } \\
1994-2011\end{array}$ & $\begin{array}{l}\text { Retrospective } \\
\text { study from } \\
\text { prospective } \\
\text { register }\end{array}$ & Office & 257 & $1.48 \%$ & 23.8 & $\mathrm{NI}^{*}$ & $\mathrm{NI}^{*}$ \\
\hline
\end{tabular}




\begin{tabular}{|c|c|c|c|c|c|c|c|c|c|}
\hline $\begin{array}{l}\text { Moon } 2015 \\
\text { (21) }\end{array}$ & $\begin{array}{l}\text { United } \\
\text { States }\end{array}$ & $\begin{array}{l}\text { MetropolitanPh } \\
\text { enix 2000-2012 }\end{array}$ & $\begin{array}{l}\text { Retrospective } \\
\text { study from } \\
\text { prospective } \\
\text { register }\end{array}$ & $\begin{array}{c}\text { Public } \\
\text { business/Office/ } \\
\text { workplace }\end{array}$ & 65 & $1.29 \%$ & 1.3 & NI* & $\mathrm{NI}^{*}$ \\
\hline $\begin{array}{c}\text { Malcom } \\
2004(18)\end{array}$ & $\begin{array}{l}\text { United } \\
\text { States }\end{array}$ & $\begin{array}{c}\text { Georgia State } \\
2000\end{array}$ & $\begin{array}{l}\text { Retrospective } \\
\text { study from } \\
\text { prospective } \\
\text { register }\end{array}$ & Industrial & 62 & $0.98 \%$ & 7.5 & NI* & $\mathrm{NI}^{*}$ \\
\hline $\begin{array}{c}\text { Zakaria } \\
2014(17)\end{array}$ & Singapore & $\begin{array}{l}\text { Singapore } \\
2001-2004\end{array}$ & $\begin{array}{c}\text { Retrospective } \\
\text { study from } \\
\text { prospective } \\
\text { register }\end{array}$ & $\begin{array}{c}\text { Office and } \\
\text { industrial } \\
\text { building }\end{array}$ & 63 & $2.80 \%$ & 5.0 & $\mathrm{NI}^{*}$ & $\mathrm{NI}^{*}$ \\
\hline
\end{tabular}

* Not included (no survival extractable), OHCA $=$ out of hospital cardiac arrest,Adm. $=$ Admission alive at hospital, Disch $=$ Discharge alive from hospitalCPC1/2 = Good neurological outcome (cerebral performance category 1 or 2 ) 
Table 2. Summary of meta-odds ratio (Meta-OR) of studies included in the quantitative analysis (with 95\% confidence interval or CI95\%).

\begin{tabular}{|c|c|c|c|}
\hline & $\begin{array}{l}\text { MetaOR for admission } \\
\text { alive at hospital (CI95\%), } \\
\text { Number of studies } \\
\text { (related references), Q } \\
\text { statistic }\end{array}$ & $\begin{array}{l}\text { MetaOR for discharge alive } \\
\text { from hospital (Number of } \\
\text { studies) (CI95\%), Number of } \\
\text { studies, Q statistic }\end{array}$ & $\begin{array}{l}\text { MetaOR for a good } \\
\text { neurological outcome i.e. } \\
\text { CPC1/2 (CI95\%), Number } \\
\text { of studies, Q statistic }\end{array}$ \\
\hline All OHCA & $\begin{array}{l}2.1(1.3-3.2), n=3 \\
(4,11,15), P=0.136\end{array}$ & $\begin{array}{l}2.4(1.3-4.4), n=4 \\
(10,11,13,14), P=0.051\end{array}$ & $\begin{array}{l}\text { Not enough studies, } n=1 \\
(15), \text { OR=3.6 }(1.5-8.6)\end{array}$ \\
\hline All treatable OHCA & $\begin{array}{l}1.9(1.5-2.3), n=4 \\
(5,11,12,15), P=0.402\end{array}$ & $\begin{array}{l}2.4(1.6-3.7), \mathrm{n}=7 \\
(3,5,10,11,13,14,16), \\
\mathrm{P}=0.002\end{array}$ & $\begin{array}{l}5.9(2.7-13.0), n=3(3,5,15) \\
P=0.037\end{array}$ \\
\hline $\begin{array}{l}\text { All treatable OHCA, only } \\
\text { high quality studies } \\
\text { included }\end{array}$ & $\begin{array}{l}2.0(1.6-2.4), n=2(5,15) \\
P=0.521\end{array}$ & $\begin{array}{l}2.9(1.8-4.7) \\
n=5(3,5,13,14,16), P=0.041\end{array}$ & $\begin{array}{l}5.9(2.7-13.0), n=3(3,5,15), \\
P=0.037\end{array}$ \\
\hline $\begin{array}{l}\text { OHCA restricted to } \\
\text { workplaces or other } \\
\text { public sites }\end{array}$ & $\begin{array}{l}\text { Not enough studies, } n=1 \\
(5), \text { OR=1.1 }(0.8-1.4)\end{array}$ & $\begin{array}{l}1.1(0.8-1.6) \\
n=6(3,5,10,3,14,16), P=0.054\end{array}$ & $\begin{array}{l}1.4(0.5-3.9), n=3(3,5,15), \\
P=0.038\end{array}$ \\
\hline
\end{tabular}

CPC Cerebral performance category 
Figure 1.Flow chart.

Figure 1 : Flow Chart
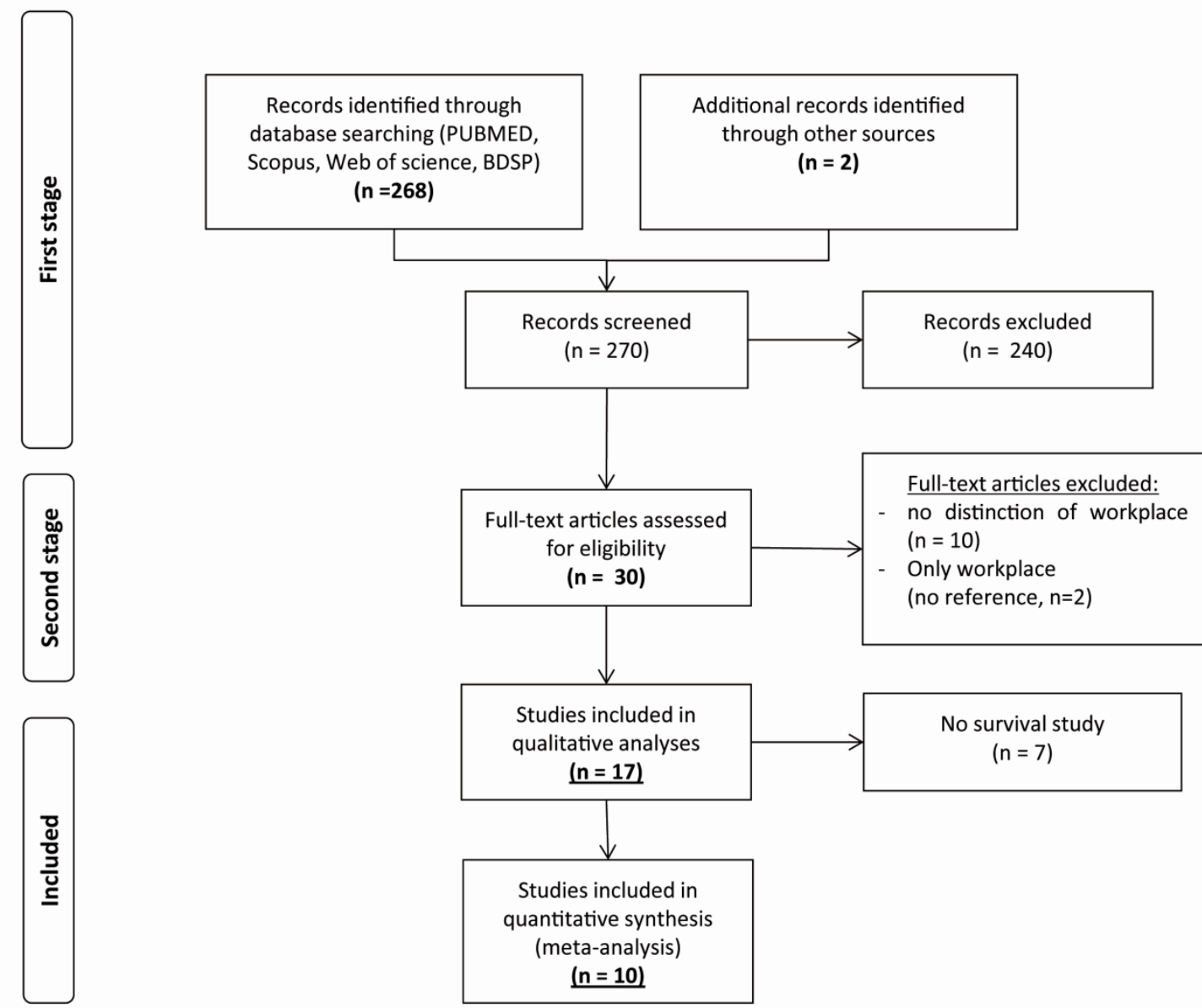
Figure 2. Related Forrest plots of table 2

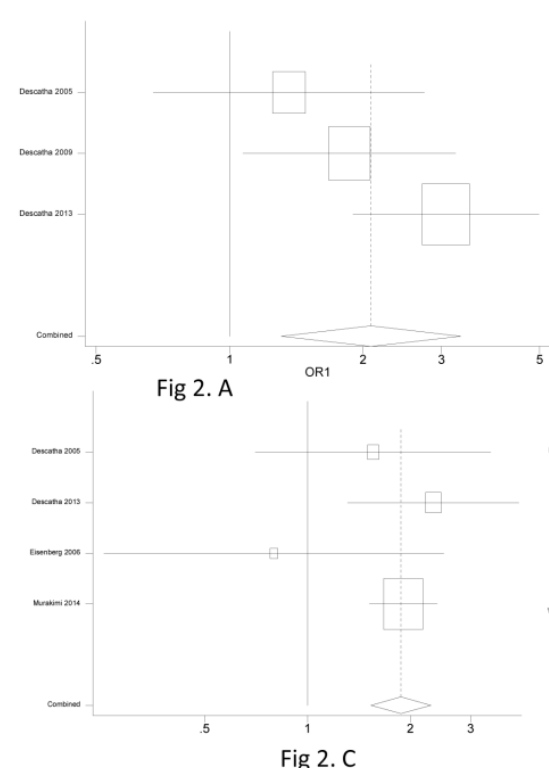

Figure 2. Forrest plots
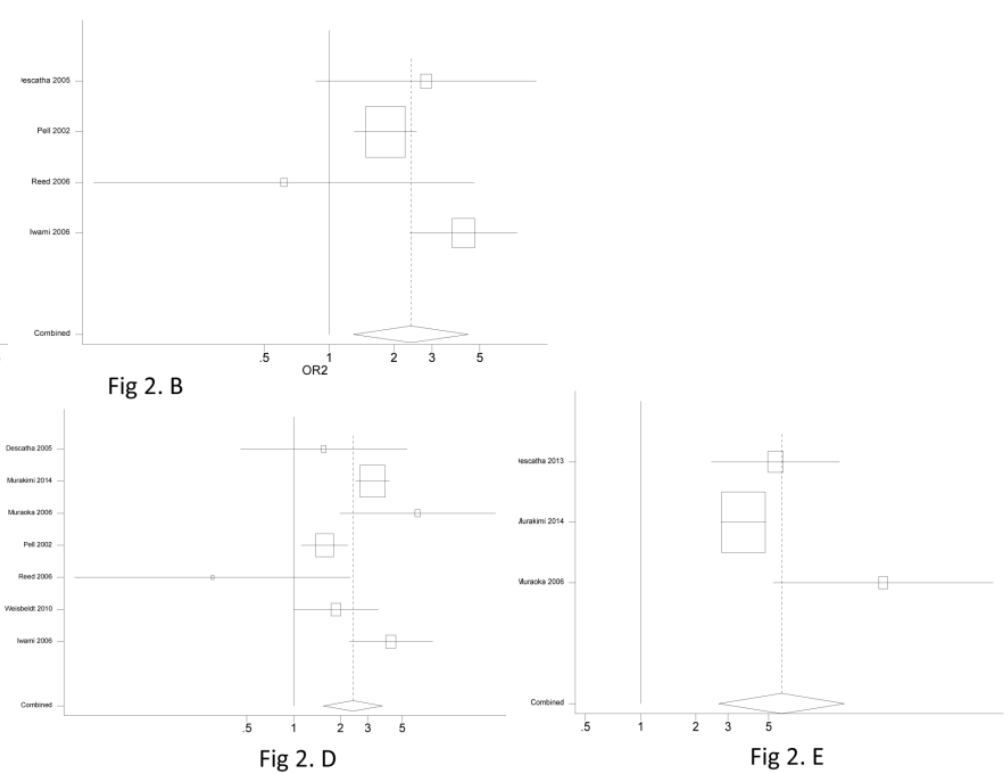

A : All OHCA for admission alive at hospital

B : All OHCA for discharge alive from hospital

C : All treatable OHCA for admission alive at hospital

D : All treatable OHCA for discharge alive from hospital

E : All treatable OHCA for a good neurological outcome

i.e. $\mathrm{CPC} 1 / 2$

F : OHCA restricted to workplaces or other public sites for discharge alive from hospital

G : OHCA restricted to workplaces or other public sites for a good neurological outcome i.e. CPC1/2
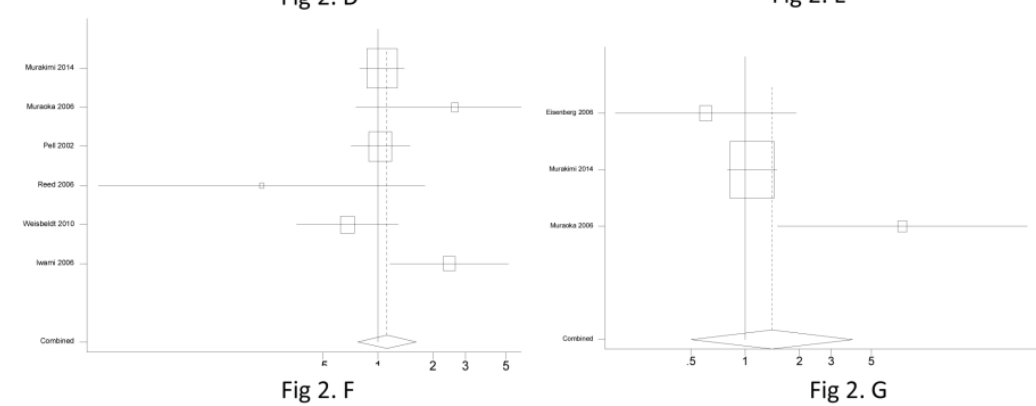